\title{
The Impact of Spokes-Characters on Customer Loyalty
}

\author{
Aibala Kassymbayeva ${ }^{1}$ \\ ${ }^{1}$ School of Business Administration, South China University of Technology, Guangzhou, China \\ Correspondence: Aibala Kassymbayeva, Room 203, West 1 Dormitory Building, South China University of \\ Technology, No.381, Wushan Road, Tianhe District, Guangzhou, China. E-mail: kas_akbala@mail.ru
}

Received: April 17, 2017

Accepted: May 3, 2017

Online Published: June 7, 2017

doi:10.5539/ijbm.v12n7p162

URL: https://doi.org/10.5539/ijbm.v12n7p162

\begin{abstract}
This study aims to explore the relationship among spokes-characters and customer loyalty. To reach the purpose, a conceptual model has been constructed, with three variables, including spokes-characters, customer loyalty and brand trust. Specifically, spokes-characters (SC) is designed as the independent variable, brand trust (BT) as the mediating variable, and customer loyalty (CL) as dependent variable. This study has collected 332 effective samples both online and offline. All the respondents are common consumers with consumption experience. The collected data was processed and analyzed by regression analysis and structural equation modeling with SPSS and AMOS software. The result of this study indicated that spokes-characters have significant impact to customer loyalty, and brand trust has mediating effect on the relationship between spokes-characters and customer loyalty. These finding are important to brand promotion of companies, which suggest that spokes-characters can also play a positive role and marketing managers should attach more importance to spokes-characters.
\end{abstract}

Keywords: spokes-characters, customer loyalty, brand trust, mediating effect

\section{Introduction}

Brand, loyalty has always been the popular business keywords, and business managers are always thinking about how to shape a good brand image and improve customer loyalty (Deng, Tao \& Ma, 2004). The increasingly fierce competition and the homogenization of trend in product have made this problem harder. Since 1980s, brand economy and consumer age have begun. Consumers no longer only cares about price or quality of the products, but gradually take the product brand as a basis for decision-making of buying behavior (Aaker, 1991). On this background, how to shape a good image of brand to impress consumers and promote customer loyalty, have become a core question that entrepreneurs must think twice. Companies have resorted to all means to solve this problem, by taking brand marketing as an important strategy, being committed to brand packaging and publicity.

One of the best practices for entrepreneurs to brand marketing is to shape a spokesperson with fame. Star spokesperson is well-known to consumers, and is widely used in marketing. Spokesperson strategy is working benefiting from their influence and appeal. However, scholars have pointed out that the success of spokesperson is due to a special economic system (Dong \& Jin, 1991), in which consumers can easily pick the spokesperson brand up from a number of brands. However, countless star spokesperson appear, so that consumers gradually feel numb and aesthetic fatigue. In addition, star spokesperson has many uncertain and uncontrollable factors, which may even have a negative impact to brands. Studies have proved that consumers will passed their dissatisfaction with the spokesperson to the brand or product (Peng \& Cao, 2011). In order to make up for some of the shortcomings of star spokesperson, many companies choose to use spokes-characters to carry out brand promotion. Spokes-characters is a symbolic symbol of human or other biology to deliver message of personality, culture, and value of a brand, and it is an important part of intangible assets of enterprises (Zhang, 2013). There are many successful examples in marketing practice, such as Disney Mickey Mouse, McDonald, Haier brothers and so on. It is worth mentioning that ten outstanding brands that "Advertising Age" votedare all spokes-characters.

Spokes-characters have become an important role in brand strategy. As a result, people in both practice and academic areas pay more and more attention to spokes-characters. 
Therefore, how to shape suitable spokes-characters, to develop a good brand image, to get consumer trust, to improve loyalty, is the crucial issue for the enterprises. As domestic research in this area is relatively scarce, this study aims to explore the relationship among spokes-characters and customer loyalty and answer the question listing below:

(1) Whether spokes-characters significantly affect customer loyalty?

(2) Whether brand trust has mediating effect in the relationship between spokes-characters and customer loyalty?

\section{Literature Review}

\subsection{Spokes-characters}

The emergence and development of the brand gave birth to brand spokesperson. Mowen and Brown (1980) considered that spokesperson refers to those who express their own identity with product or brand in the advertisement, which will influence the consumer's attitude towards the advertisement. Zhou (2009) thought that the spokesperson could pass positive information of the brand to the consumers, and their brand recognition and consumer behavior would be impacted. Kamen, Azhari, \& Kragh (1979) divided spokesperson into four types according to their role in advertising, including testimonial, endorser, actor, and spokesperson. Some researches classified spokesperson based on their social identities, including stars, specialist, consumer, enterprise CEO, third-party organization, etc. (Freiden, 1984; Dwane, Abhijit, 2001; Callcott, Alvey, 1991).

In addition to real people, virtual image can also play the role of brand spokesperson to achieve the effect of publicity. Aaker (1991) pointed out that brand spokesperson is a general concept, which should include some virtual cartoon image that also can provide special information for the brand or product delivery service. Callcott and Alvey (1991) argued that spokes-characters is a non-humanized role that a business uses for promotion of a product or brand. Judith and Ronald (2004) deemed that spokes-characters not only include some non-human virtual characters, but also some virtual human roles, such as Ronald McDonald, who is not real, but modeled on human beings. Spokes-characters have been applied in marketing for a long history and have obtained significant effects. Besides, spokes-characters belongs to the enterprise's intangible assets, which is designed based on the background of enterprise, to convey the unique spirit or personality of the brand (Callcott, Lee, 1984; Callcott, Phillips, 2001). Additional, some scholars defined spokes-characters from the perspective of symbolic analysis. Zhou (2008) said spokes-characters uses image of human or other biological image as a special brand symbol. Zhang (2013) defined that spokes-characters is a symbolic symbol of human or other biology to deliver message of personality, culture, and value of a brand, and it is an important part of intangible assets of enterprises.This study agrees with Zhang Ning's definition of spokes-characters.

There are a lot of research on the attributes of spokes-characters. Some empirical studies already have proved that some attributes of spokes-characters, including credibility, attractiveness, expertise, likability, nostalgia, trustworthiness and relevance, have significantly effect on customer's brand awareness and purchase behavior (Callcott, Lee, 1994; Spears, Mowen \& Chakraborty, 1996; Judith, Ronald, 2004).

Callcott and Alvey (1991) ascribed the good propaganda of spokes-characters to its nostalgia. Further, Callcott and Phillips (1996) shows that, in addition to nostalgia, expertise and relevance to the product can also influence the propaganda of spokes-characters. Swami (2008) found that the attractiveness and friendliness attributes were also factors that influenced consumer attitudes towards the brand. Garretson and Niedrich (2004) found that credibility has a significant impact on the consumer's brand attitude, nostalgia and expertise affect credibility, and relevance has no significant effect on credibility. Chang (2008) revised the model proposed by Garretson and Niedrich (2004) and considered that the perception of spokes-characters is a second-order factor, manifested as three first-order factors: likability, relevance and expertise. Among them, likability is the most important factor, followed by relevance and expertise. This study refers to Chang (2008) of the dimension of spokes-characters.

\subsection{Customer Loyalty}

At the beginning, scholars tend to explain the customer loyalty from the behavior point of view, that high-frequency of continuous purchase is customer loyalty. Jacoby and Chestnut (1978) directly regarded over three times of buying as the performance of customer loyalty. However, some scholars argued that these kind of definitions only focus on the purchase behavior of consumers but the mental activity, so attitudinal loyalty is came up. Bowen (1952) pointed out that customer loyalty also shows that consumers are willing to be part of the brand. Besides, there are some definitions are based on both behavior and mental activity. Gremler and Brown (1996) thought that loyalty is continuous buying and positive evaluation to a brand and its products, and customers will continue to buy when they add new products. 
What are the factors that affect and drive customer loyalty? In fact, many scholars have discussed this, but so far, no unified understanding has arrived. The study summarized several factors including customer satisfaction and customer trust.

There are a lot of research that prove customer satisfaction will affect customer loyalty. Customer satisfaction theory advocates that, customer satisfaction is an important driver of customer loyalty, which facilitates and maintains loyalty, the customer is more satisfied, continued purchase will be more, and loyalty will be more persistent (Kotler, 1973). Zhang, Tian, \& Zhu (2003) confirmed the relationship between perceived performance, satisfaction and loyalty. Ma and Zhang's (2003) analysis of factors affecting customer Loyalty has confirmed that customer satisfaction is one of the important factors.

Moorman, Christine \& Zaltman (1992) defined trust as one party willing to trust the other party. From a sociological point of view, the trust relationship between a consumer and an organization or brand can produce a deeper benefit than satisfaction (Gwinner, Gremler, \& Bitner, 1998). Fowler (2003) used empirical studies to demonstrate a significant positive relationship between trust and loyalty. Dwyer, Schurr, \& Oh. (1987) considers that trust is the main driver of consumers' decision to maintain a long-term relationship.

\subsection{Brand Trust}

Trust is used widely in the field of psychology, social sciences and so on. Rotter (1967) defines trust from a psychological point of view as individual expectation to be able to trust others. Worchel (1979) analyzes trust from the perspective of social science: individuals want to be able to rely on others while perceiving the existence of risk, which is based on the understanding of others.

The definition of brand trust, scholars gave on previous understanding of the trust. Lau and Lee (1999) argues that brand trust is the willingness of consumers to trust a brand when they perceive the risk, which is due to their positive expectation to the brand. Delgado, Munuera and Yagüe (2003) consider that brand trust is a sense of security that consumers gain from a brand. Yuan (2007) regards brand trust is the willingness of consumers to recognize a brand whiling perceiving risk, which is based on the positive expectations of the brand's quality and its fulfillment.

Studies on the dimension of brand trust, roughly is divided into three cases: one dimension, two dimensions, and three dimensions. The two-dimensional structure is used most widely. Erden and Swait (1998) proposed a two-dimensional structural model, including trustworthiness (how much is the brand willing to fulfill the commitment to consumer) and expertise (the ability that brand can fulfill the commitment to consumer). Besides, Delgado-Ballester (2003) developed a two-dimensional structure of brand trust, including brand reliability and brand intentionality. Brand liability refers to the ability of the brand itself to achieve commitment to the consumer, and brand intentionality is how fit between brand and the consumer. This article refers to the brand trust two-dimensional structure that Delgado-Ballester put forward.

\section{Theoretical Model and Hypotheses}

\subsection{Theoretical Model}

According to the theory of "Cognition-Emotion-Behavior" in the field of psychology, consumers can be aware of spokes-characters and their attributes, and form a pleasant emotion, as well as a deep impression, during the consumption of the brand product or service, which will be ultimately contributed to loyalty.

Because spokes-characters does not really exist, but is a virtual cartoon image. The specificity may influence customer loyalty through the brand. That is, the consumer's attitude to spokes-characters may be transferred to its brand, and then affect the customer Loyalty.

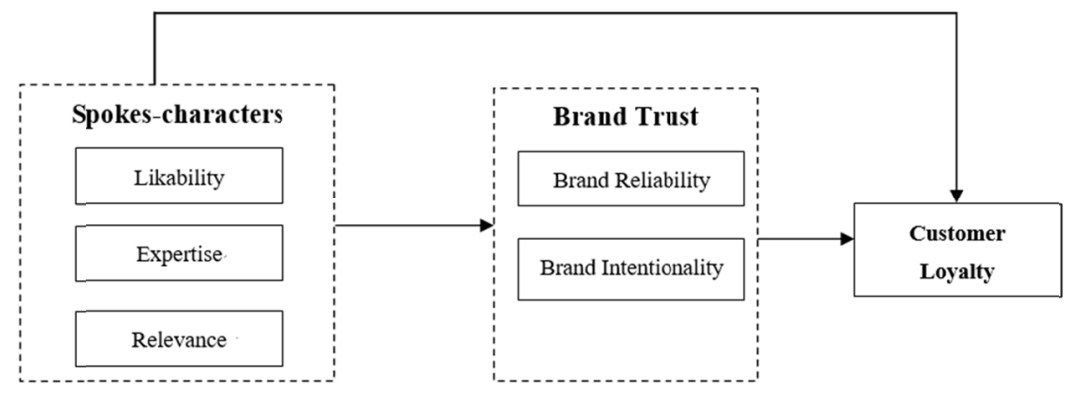

Figure 1 Theoretical model of this study 
In summary, this paper constructs a conceptual model with attributes of spokes-characters, brand trust and customer loyalty, as shown in Figure 3-1. Specifically, three dimensions (likability, expertise, relevance) of spokes-characters are independent variables, two dimensions of brand trust (brand reliability and brand intentionality) are mediating variable, and customer loyalty is dependent variable.

\subsection{Hypotheses}

\subsubsection{Relationship between Spokes-Characters and Customer Loyalty}

Spokes-characters is a special form of the spokesperson. Many studies have shown that spokes-characters can help consumers have a good understanding to the brand, and improve acceptance and purchase intention of consumers (Judith, Folse, Netemeyer, \& Scot, 2012; Mize, Kinney, 2008). The spokes-characters represents the image of the brand. Lin (2012) believes that consumer will have a deep impression to likability of the spokes-characters. Chang (2008) confirms that consumers can perceive the attributions of spokes-characters, like likability, expertise, relevance. Therefore, this paper thinks that the attributes of spokes-characters will positively affect customer loyalty, and raises the following assumptions:

H1: The attributes of spokes-characters have a significant positive impact on customer loyalty: the higher likability, the higher customer loyalty (H1a); the higher expertise, the higher customer loyalty (H1b); the higher relevance, the higher customer loyalty (H1c).

\subsubsection{Relationship between Spokes-Characters and Brand Trust}

Some scholars believe that if the consumer is satisfied with the spokes-characters, they will endorse the brand. The spokes-characters, to some extent, represents the image of a brand. Zeithaml (1988) points that consumers tend to judge whether a brand is trustworthy in two ways. The first is the inherent characteristics of the brand, and the second is some external features such as historical background, visibility, and spokesperson, etc. Therefore, consumers will observe the attributes of spokes-characters, such as likability, expertise, relevance and others, to reduce the uncertainty of the brand, and form the brand awareness, and improve the favor to the brand (Dwane,1999). Therefore, spokes-characters has become one of the important factors for consumer's trust. Therefore, this paper thinks that the attributes of spokes-characters will positively affect brand trust, and raises the following assumptions:

H2: The attributes of spokes-characters have a significant positive impact on brand reliability: the higher likability, the higher brand reliability (H2a); the higher expertise, the higher brand reliability (H2b); the higher relevance, the higher brand reliability $(\mathrm{H} 2 \mathrm{c})$.

H3: The attributes of spokes-characters have a significant positive impact on brand intentionality: the higher likability, the higher brand intentionality (H3a); the higher expertise, the higher brand intentionality (H3b); the higher relevance, the higher brand intentionality $(\mathrm{H} 3 \mathrm{c})$.

\subsubsection{Relationship between Brand Trust and Customer Loyalty}

Lau and Lee (1999) show that brand trust can significantly affect brand loyalty. Delgado-Ballester (2003) found that brand trust can significantly affect loyalty, and further, loyalty will have an impact on brand equity in an empirical study of brand trust and assets. Sweeneya and Swait (2008) found that the higher reliability of the brand, the consumer is more willing to express loyalty. Therefore, this paper thinks that brand trust will positively affect customer loyalty, and raises the following assumptions:

H4: Brand trust have a significant positive impact on customer loyalty

H4a: Brand reliability have a significant positive impact on customer loyalty

$\mathrm{H} 4 \mathrm{~b}$ : Brand intentionality have a significant positive impact on customer loyalty

\subsubsection{Mediate Effect of Brand Trust}

Many researches have confirmed that spokes-characters represents the image of a brand, which will affect the consumer's perception of the quality of the brand, and further will affect customer loyalty. Dipayan, Abhijit \& Neel (2006) have shown that spokes-characters will make consumers have a deep impression of the brand, and enhance recognition and trust to the brand and product, so that consumers are more likely to generate a continuous purchase, and loyalty.

H5: Brand reliability have mediate impact on the relationship between attributes of spokes-characters and customer loyalty

H5a: Brand reliability have mediate impact on the relationship between likability and customer loyalty 
H5b: Brand reliability have mediate impact on the relationship between expertise and customer loyalty

H5c: Brand reliability have mediate impact on the relationship between relevance and customer loyalty

H6: Brand intentionality have mediate impact on the relationship between attributes of spokes-characters and customer loyalty

H6a: Brand intentionality have mediate impact on the relationship between likability and customer loyalty

H6b: Brand intentionality have mediate impact on the relationship between expertise and customer loyalty

H6c: Brand intentionality have mediate impact on the relationship between relevance and customer loyalty

\section{Method}

\subsection{Samples and Measures}

This study takes the consumers as the respondents. To ensure the representativeness of the subjects, this study selected China's largest online questionnaire survey platform "SOJUMP" (website: http: // www.Sojump.com/) to conduct a questionnaire survey. SOJUMP has a sample library with 2.6 million members, related to all age groups, industry, having a high representativeness.

A total of 356 questionnaires were collected from the survey. Then some invalid questionnaires were removed for the purification after the code. Finally, 332 valid questionnaires were selected and the effective rate was $93.2 \%$. The demographic information of the sample is shown in Table 1.

Table 1. Demographic information

\begin{tabular}{llll}
\hline & Item & Frequency & Percentage \\
\hline \multirow{3}{*}{ Gender } & Male & 182 & 51.1 \\
& Female & 174 & 48.9 \\
& $<=20$ & 34 & 10.24 \\
Age & $21-30$ & 167 & 50.30 \\
& $31-40$ & 112 & 33.73 \\
& $>40$ & 19 & 5.72 \\
\multirow{5}{*}{ Education } & Middle school & 0 & 0.00 \\
& High school or secondary school & 5 & 1.51 \\
& Post-secondary school & 21 & 6.33 \\
& Undergraduate & 138 & 41.57 \\
& Graduate & 168 & 50.60 \\
\hline
\end{tabular}

The operational definition and scale of variables have a decisive effect on the results of the study. Therefore, the measurement of the variables in this study are all authority scales, to meet the requirements of content validity. In addition, scales were used Likert5-points measure. The interviewees express their consent to the question by checking the number 1-5.

The scale of attributes of spokes-characters refers to the research of Zhang (2013), including 10 items. A sample item is: "That spokes-character is likable"; the scale of customer loyalty refers to the research of Yoo and Donthu (2001), including three items. A sample item is: "I am a loyal customer of that brand"; the scale of brand trust refers to the research of Delgado-Ballester (2013), including sixitems. A sample item is: "I am very confident about the products of that brand".

\subsection{Preliminary Research}

This study did a pre-research within a small scope, to ensure effectiveness of the various questions by doing EFA test with the data. The EFA test result is shown in the table 2. As we can see, the variable of spokes-character has rotated three factors, customer loyalty has rotated one factor, and brand trust has rotated two, which indicates the scales have good validity. 
Table 2. EFA test result of preliminary research

\begin{tabular}{|c|c|c|c|c|c|c|c|c|c|}
\hline \multicolumn{2}{|c|}{ Variable } & \multirow{2}{*}{$\frac{\text { item }}{\mathrm{L} 1}$} & \multirow{2}{*}{$\frac{1}{0.222}$} & \multirow{2}{*}{$\frac{2}{0.092}$} & \multirow{2}{*}{$\begin{array}{c}3 \\
0.813\end{array}$} & Variable & \multirow{2}{*}{$\frac{\text { item }}{\text { CL1 }}$} & \multicolumn{2}{|c|}{1} \\
\hline Spokes-chara & \multirow{3}{*}{ likability } & & & & & \multirow[t]{3}{*}{ Customer loyalty } & & \multicolumn{2}{|c|}{0.831} \\
\hline \multirow[t]{11}{*}{ cters } & & $\mathrm{L} 2$ & 0.224 & 0.176 & 0.790 & & CL2 & \multicolumn{2}{|c|}{0.833} \\
\hline & & L3 & 0.044 & 0.349 & 0.673 & & CL3 & \multicolumn{2}{|c|}{0.812} \\
\hline & \multirow{4}{*}{ expertise } & E1 & 0.776 & 0.131 & 0.253 & KMO & \multicolumn{3}{|c|}{0.696} \\
\hline & & E2 & 0.714 & 0.321 & 0.130 & Variable & item & 1 & 2 \\
\hline & & E3 & 0.537 & 0.190 & 0.268 & Brand reliability & BF1 & 0.742 & 0.194 \\
\hline & & E4 & 0.858 & 0.110 & 0.019 & Trust & $\mathrm{BF} 2$ & 0.787 & 0.251 \\
\hline & \multirow{3}{*}{ relevance } & $\mathrm{R} 1$ & 0.180 & 0.850 & 0.188 & & BF3 & 0.774 & 0.131 \\
\hline & & $\mathrm{R} 2$ & 0.303 & 0.708 & 0.163 & Brand & BI1 & 0.333 & 0.643 \\
\hline & & $\mathrm{R} 3$ & 0.154 & 0.806 & 0.219 & intentionality & BI1 & 0.150 & 0.852 \\
\hline & \multirow{2}{*}{ KMO } & & \multirow{2}{*}{\multicolumn{2}{|c|}{0.841}} & & & BI1 & 0.145 & 0.799 \\
\hline & & & & & & $\mathrm{KMO}$ & & 0.788 & \\
\hline
\end{tabular}

\section{Data Analysis}

\subsection{Reliability, Validity and Correlation}

Reliability analysis refers to the possibility of using the same observation method to obtain similar observations (results) for the same subject. In this study, Cronbach's $\alpha$ was used to measure the internal reliability of the scale. It is generally acknowledged, the greater Cronbach's $\alpha$, the better the internal reliability. The result of reliability of this study is shown in table 3. Cronbach's $\alpha$ of all the variablesare greater than 0.6 , indicating that the collected data has good internal reliability.

Table 3. EFA test result of preliminary research

\begin{tabular}{|c|c|c|c|c|c|}
\hline \multicolumn{2}{|c|}{ Variable and dimensions } & \multirow{2}{*}{$\frac{\text { Item }}{\text { L1 }}$} & \multirow{2}{*}{$\frac{\text { CITC }}{0.589}$} & \multirow{2}{*}{$\frac{\text { Corrected Item-Total Correlation }}{0.593}$} & \multirow{2}{*}{ Cronbach's $\alpha$} \\
\hline Spokes-characters & & & & & \\
\hline & \multirow[t]{3}{*}{ Likability } & $\mathrm{L} 2$ & 0.591 & 0.588 & \multirow[t]{3}{*}{0.728} \\
\hline & & L3 & 0.473 & 0.728 & \\
\hline & & E1 & 0.600 & 0.691 & \\
\hline & \multirow{4}{*}{ Expertise } & E2 & 0.600 & 0.691 & \multirow{4}{*}{0.766} \\
\hline & & E3 & 0.478 & 0.753 & \\
\hline & & E4 & 0.592 & 0.698 & \\
\hline & & R1 & 0.683 & 0.643 & \\
\hline & \multirow[t]{2}{*}{ Relevance } & $\mathrm{R} 2$ & 0.570 & 0.767 & \multirow[t]{2}{*}{0.784} \\
\hline & & $\mathrm{R} 3$ & 0.620 & 0.712 & \\
\hline \multirow{3}{*}{\multicolumn{2}{|c|}{ Customer loyalty }} & CL1 & 0.590 & 0.686 & \multirow{3}{*}{0.762} \\
\hline & & CL2 & 0.510 & 0.752 & \\
\hline & & CL3 & 0.585 & 0.693 & \\
\hline \multirow[t]{6}{*}{ Brand trust } & Brand reliability & $\mathrm{BF} 1$ & 0.662 & 0.641 & \multirow{3}{*}{0.776} \\
\hline & \multirow{5}{*}{ Brand intentionality } & $\mathrm{BF} 2$ & 0.549 & 0.765 & \\
\hline & & $\mathrm{BF} 3$ & 0.634 & 0.674 & \\
\hline & & BI1 & 0.451 & 0.640 & \multirow{3}{*}{0.681} \\
\hline & & $\mathrm{BI} 2$ & 0.558 & 0.499 & \\
\hline & & BI3 & 0.477 & 0.610 & \\
\hline
\end{tabular}

Validity is the degree that the measurement tool can accurately measure what is required, including content validity, convergent validity and discriminant validity.

On content validity. Since the measuring items used in this study are from the mature scale developed and verified by predecessors, content validity is good.

On convergent validity. This study measures convergent validity by the value of CR and AVE (also called CFA test). Generally, if CR is greater than 0.6, and AVE is greater than 0.5 , the convergent validity is regarded as good. The result of CFA is shown in table 4, we can learn from the result that CR and AVE of all variables are 
up to standard. Therefore, convergent validity is good.

Table 4. Result of CFA model

\begin{tabular}{|c|c|c|c|c|c|}
\hline Variable & Item & Factor Loading & 1-SMC & $\mathrm{CR}$ & AVE \\
\hline \multirow{3}{*}{ Likability } & $\mathrm{L} 1$ & 0.752 & 0.434 & 0.749 & 0.501 \\
\hline & L2 & 0.762 & 0.419 & & \\
\hline & L3 & 0.597 & 0.644 & & \\
\hline \multirow{4}{*}{ Expertise } & E1 & 0.733 & 0.463 & 0.803 & 0.505 \\
\hline & E2 & 0.730 & 0.467 & & \\
\hline & E3 & 0.685 & 0.531 & & \\
\hline & E4 & 0.692 & 0.521 & & \\
\hline \multirow{3}{*}{ Relevance } & $\mathrm{R} 1$ & 0.851 & 0.276 & & \\
\hline & $\mathrm{R} 2$ & 0.649 & 0.579 & & \\
\hline & $\mathrm{R} 3$ & 0.730 & 0.467 & 0.790 & 0.559 \\
\hline \multirow{3}{*}{$\begin{array}{l}\text { Customer } \\
\text { loyalty }\end{array}$} & CL1 & 0.709 & 0.497 & & \\
\hline & CL2 & 0.748 & 0.440 & & \\
\hline & CL3 & 0.702 & 0.507 & 0.763 & 0.519 \\
\hline \multirow{3}{*}{$\begin{array}{l}\text { Brand } \\
\text { reliability }\end{array}$} & $\mathrm{BF} 1$ & 0.816 & 0.334 & & \\
\hline & $\mathrm{BF} 2$ & 0.627 & 0.607 & & \\
\hline & $\mathrm{BF} 3$ & 0.758 & 0.425 & 0.780 & 0.545 \\
\hline \multirow{3}{*}{$\begin{array}{c}\text { Brand } \\
\text { intentionality }\end{array}$} & BI1 & 0.760 & 0.422 & & \\
\hline & $\mathrm{BI} 2$ & 0.787 & 0.381 & & \\
\hline & $\mathrm{BI} 3$ & 0.598 & 0.642 & 0.761 & 0.518 \\
\hline Fit Index & & $\chi^{2 / \mathrm{df}=1.416 ; \quad \mathrm{RMSEA}=0.035 ;}$ & $\mathrm{GFI}=0.943 ;$ & AGFI $=0.921 ; \quad$ CFI $=0.975 ;$ & $\mathrm{NFI}=0.920$ \\
\hline
\end{tabular}

On discriminant validity. This study measures discriminant validity by comparing the value of AVE with the standardized coefficient (observed variable and other variables). Generally, if AVE is greater than standardized coefficient, the convergent validity is regarded as good. The result of discriminant validity is shown in table 5; we can learn from the result that all the AVE are greater than standardized coefficient. Therefore, discriminant validity is good.

Table 5. Result of discriminant validity

\begin{tabular}{lcccccc}
\hline \multicolumn{1}{c}{ Variable } & 1. & 2 & 3 & 4 & 5 & 6 \\
\hline 1. Likability & $\mathbf{0 . 5 0 1}$ & & & & & \\
2. Expertise & 0.191 & $\mathbf{0 . 5 0 5}$ & & & & \\
3. Relevance & 0.218 & 0.197 & $\mathbf{0 . 5 5 9}$ & & & \\
4. Customer loyalty & 0.276 & 0.255 & 0.321 & $\mathbf{0 . 5 1 9}$ & & \\
5. Brand reliability & 0.222 & 0.226 & 0.243 & 0.310 & $\mathbf{0 . 5 4 5}$ & \\
6.Brand intentionality & 0.248 & 0.280 & 0.228 & 0.236 & 0.182 & $\mathbf{0 . 5 1 8}$ \\
\hline
\end{tabular}

Before regression analysis, this paper first did a correlation analysis. The result is shownin table 6 . We can see that there is a significant correlation between six variables, which provides a basis for subsequent regression analysis.

Table 6. Correlations of variables

\begin{tabular}{|c|c|c|c|c|c|c|}
\hline Variable & 1. & 2 & 3 & 4 & 5 & 6 \\
\hline 1. Likability & 1 & & & & & \\
\hline 2. Expertise & $0.437 * *$ & 1 & & & & \\
\hline 3. Relevance & $0.467 * *$ & $0.444 * *$ & 1 & & & \\
\hline 4. Customer loyalty & $0.525 * *$ & $0.505 * *$ & $0.567 * *$ & 1 & & \\
\hline 5. Brand reliability & $0.471 * *$ & $0.475 * *$ & $0.493 * *$ & $0.557 * *$ & 1 & \\
\hline 6.Brand intentionality & $0.498 * *$ & $0.529 * *$ & $0.477 * *$ & $0.486 * *$ & $0.427 * *$ & 1 \\
\hline
\end{tabular}




\subsection{Result of Regression Analysis}

This study tests the hypothesis by regression analysis with SPSS software, to find out the relationship between attributes of spokes-characters, brand trust and customer loyalty, and verify the mediating effect of brand trust.

\subsubsection{Linear-Regression Analysis}

\section{Hypothesis testing of attributes of spokes-characters and customer loyalty}

The multiple regression results of the attributes of spokes-characters (likability, expertise and relevance), as independent variables, and customer loyalty as dependent variable, are as table 7 . We can see that the coefficient of three independent variables are significant, which proves that likability, expertise and relevance have significant and positive effect to customer loyalty. Therefore, hypothesis H1a, H1b, H1c are all passed.

Table 7. Hypothesis result between spokes-characters and customer loyalty

\begin{tabular}{cccccc}
\hline Variable & Standardized coefficient Beta & $\mathrm{T}$ & $\Delta \mathrm{F}$ & $\mathrm{df1}$ & $\mathrm{df2}$ \\
\hline Constant & $0.917^{* * *}$ & 4.277 & & & \\
Likability & $0.261^{* * *}$ & 5.418 & \multirow{2}{*}{$89.653^{* * *}$} & 3 & 327 \\
Expertise & $0.241^{* * *}$ & 5.042 & & & \\
Relevance & $0.338^{* * *}$ & 6.951 & & & \\
\hline
\end{tabular}

\section{Hypothesis Testing of Attributes of Spokes-Characters and Brand Trust}

Similarly, the multiple regression results of the attributes of spokes-characters (likability, expertise and relevance), as independent variables, and brand trust (brand reliability, brand intentionality) as dependent variable, are as table $8 \&$ table 9 . We can see that the coefficient of all independent variables are significant, which proves that likability, expertise and relevance have significant and positive effect to brand reliability and brand intentionality. Therefore, hypothesis H2a, H2b, H2c, H3a, H3b, H3c, are all passed.

Table 8 . Hypothesis result between spokes-characters and brand reliability

\begin{tabular}{cccccc}
\hline Variable & Standardized coefficient Beta & $\mathrm{T}$ & $\Delta \mathrm{F}$ & $\mathrm{df1}$ & $\mathrm{df2}$ \\
\hline Constant & $1.215^{* * *}$ & 5.222 & & & \\
Likability & $0.232^{* * *}$ & 4.464 & & & \\
Expertise & $0.256^{* * *}$ & 4.974 & $62.835^{* * *}$ & 3 & 327 \\
Relevance & $0.271^{* * *}$ & 5.198 & & & \\
\hline
\end{tabular}

Table 9. Hypothesis result between spokes-characters and brand intentionality

\begin{tabular}{|c|c|c|c|c|c|}
\hline Variable & Standardized coefficient Beta & $\mathrm{T}$ & $\Delta \mathrm{F}$ & df1 & $\mathrm{df} 2$ \\
\hline Constant & $1.164 * * *$ & 5.610 & \multirow{4}{*}{$73.160 * * *$} & \multirow{4}{*}{3} & \multirow{4}{*}{327} \\
\hline Likability & $0.256 * * *$ & 5.069 & & & \\
\hline Expertise & $0.324 * * *$ & 6.495 & & & \\
\hline Relevance & $0.213 * * *$ & 4.208 & & & \\
\hline
\end{tabular}

\section{Hypothesis Testing of Brand Trust and Customer Loyalty}

The multiple regression results of the brand trust (brand reliability, brand intentionality), as independent variables, and customer loyalty as dependent variable, are as table 10 . We can see that the coefficient of twoindependent variables are significant, which proves that brand reliability and brand intentionality have significant and positive effect to customer loyalty. Therefore, hypothesis H4a, H4bare all passed.

Table 10. Hypothesis result between brand trust and customer loyalty

\begin{tabular}{llllll}
\hline Variable & Standardized coefficient Beta & $\mathrm{T}$ & $\Delta \mathrm{F}$ & $\mathrm{df1}$ & $\mathrm{df2}$ \\
\hline Constant & $0.916^{* * *}$ & 3.864 & & \\
Brand reliability & $0.428^{* * *}$ & 8.948 & $103.354^{* * *}$ & 2 & 328 \\
Brand intentionality & $0.304^{* * *}$ & 6.365 & & \\
\hline
\end{tabular}




\subsubsection{Mediating Effect Analysis}

Mediating effect, that is, the independent variable affects the dependent variable through the mediating variable. The testing steps are following: 1) test if the independent variable affects the dependent variable significantly; 2) test if the independent variable affects the mediating variable significantly; 3 ) test if the independent variable and mediating variable affect the dependent variable significantly; 4) if step1 and step 2 are significant, then see the result of step 3. In step 3, if the coefficient of independent variable is insignificant, full mediating effect exists; if the coefficient of independent variable is significant and the value is lower, partial mediating effect exists. In this way, this study tests the mediating effect of brand trust.

\section{Mediating effect of brand reliability}

This study first tests the regression coefficients of the three dimensions of spokes-characters and customer loyalty, and then tests the regression coefficients of $t$ the three dimensions of spokes-characters and brand reliability. Finally, we tests the regression coefficients of the three dimensions of spokes-characters tbrand reliability to customer loyalty. The result can be seen in table 11. After adding brand reliability into the multiple regression model, the regression coefficients of three dimension of spokes-characters are all-significant, and lower, as well. Partial mediating effect exist. Therefore, hypothesis H5a, H5b, H5c are all passed.

Table 11. Result of mediating effect of brand reliability

\begin{tabular}{cccc}
\hline \multicolumn{1}{c}{ Relationship among variables } & Standardized Coefficient & Test results \\
\hline Likability & $\rightarrow$ Customer loyalty & $0.525^{* *}$ & \\
Likability & $\rightarrow$ Brand reliability & $0.471^{* * *}$ & Partial mediating effect \\
Likability & $\rightarrow$ Customer loyalty & $0.338^{* * *}$ & \\
Brand reliability & $\rightarrow$ Customer loyalty & $0.399^{* * *}$ & Partial mediating effect \\
Expertise & $\rightarrow$ Brand reliability & $0.476^{* * * *}$ & \\
Expertise & $\rightarrow$ Customer loyalty & $0.310^{* * *}$ & \\
Expertise & & $0.410^{* * *}$ & \\
Brand reliability & $\rightarrow$ Customer loyalty & $0.567^{* * *}$ & Partial mediating effect \\
Relevance & $\rightarrow$ Brand reliability & $0.493^{* * *}$ & \\
Relevance & & $0.386^{* * *}$ & \\
Relevance & $\rightarrow$ Customer loyalty & $0.367^{* * *}$ & \\
Brand reliability & & & \\
\hline
\end{tabular}

2. Mediating effect of brand intentionality

This study first tests the regression coefficients of the three dimensions of spokes-characters and customer loyalty, and then tests the regression coefficients of $t$ the three dimensions of spokes-characters and brand intentionality. Finally, we tests the regression coefficients of the three dimensions of spokes-characters + intentionality to customer loyalty. The result can be seen in table 12. After adding brand intentionality into the multiple regression model, the regression coefficients of three dimension of spokes-characters are all-significant, and lower, as well. Partial mediating effect exist. Therefore, hypothesis H6a, H6b, H6c are all passed.

Table 12. Result of mediating effect of brand intentionality

\begin{tabular}{|c|c|c|c|}
\hline Relationship among variables & & Standardized Coefficient & Test results \\
\hline Likability & $\rightarrow$ Customer loyalty & $0.525^{* *}$ & \multirow{4}{*}{ Partial mediating effect } \\
\hline Likability & $\rightarrow$ Brand intentionality & $0.498 * * *$ & \\
\hline Likability & \multirow{2}{*}{$\rightarrow$ Customer loyalty } & $0.376^{* * *}$ & \\
\hline Brand intentionality & & $0.299 * * *$ & \\
\hline Expertise & $\rightarrow$ Customer loyalty & $0.506 * * *$ & \multirow{4}{*}{ Partial mediating effect } \\
\hline Expertise & $\rightarrow$ Brand intentionality & $0.531 * * *$ & \\
\hline Expertise & \multirow{2}{*}{$\rightarrow$ Customer loyalty } & $0.345^{* * *}$ & \\
\hline Brand intentionality & & $0.304 * * *$ & \\
\hline Relevance & $\rightarrow$ Customer loyalty & $0.567 * * *$ & \multirow{4}{*}{ Partial mediating effect } \\
\hline Relevance & $\rightarrow$ Brand intentionality & $0.477 * * *$ & \\
\hline Relevance & \multirow{2}{*}{$\rightarrow$ Customer loyalty } & $0.434 * * *$ & \\
\hline Brand intentionality & & $0.280 * * *$ & \\
\hline
\end{tabular}




\section{Discussion}

\subsection{Theoretical Implications}

H1 predicted that the attributes of spokes-characters have significant effect on customer loyalty and corresponding hypothesis was supported. That is, the higherlikability/expertise/relevance, the higher customer loyalty, which is consistent with the current researches (Judith, Folse, Netemeyer, \& Scot, 2012; Mize, Kinney, 2008).

$\mathrm{H} 2$ and $\mathrm{H} 3$ predicted that the attributes of spokes-characters have significant effect on brand trust, and corresponding hypothesis was supported. That is, the higher likability/expertise/relevance, the higher brand reliability/ brand intentionality, which is consistent with the current researches (Zeithaml, 1988; Dwane, 1999).

H4 predicted that brand trust have significant effect on customer loyalty and corresponding hypothesis was supported. That is, the higher brand reliability/ brand intentionality, the higher customer loyalty, which is consistent with the current researches (Delgado-Ballester, 2003; Sweeneya, Swait, 2008).

$\mathrm{H} 5$ and $\mathrm{H} 6$ predicted that brand trust plays the mediating role in the relationship between attributes of spokes-characters and customer loyalty and corresponding hypothesis was supported. In other words, attributes of spokes-characters affects customer loyalty through brand trust, which is consistent with the current researches (Dipayan, Abhijit \& Neel, 2006).

It is worth mentioning that there is no empirical study about the relationship between attributes of spokes-characters, brand trust and customer loyalty, so this study can be regarded as a fill to in this theoretical gap.

\subsection{Practical Implications}

This study brings about several practical suggestion in marketing management as follow.

(1) Enterprises should attach importance tothe role of spokes-characters. Spokes-characters is a special type of spokesperson, belonging to the intangible assets of the enterprise, and can reach the similar effect as star spokesperson in brand publicity, to enhance customer loyalty. Besides, spokes-characters has a stronger controllability than star spokesperson, and its cost is lower. Enterprises will bear lower risk of the image or financial lost causing by the sudden negative news of star spokesperson.

(2) Enterprises should focus on some special attributes in the design of spokes-characters. This study proved that the influence that three attributes of spokes-characters affect customer loyalty are different. The biggest is relevant, followed by expertise, and likability. Additionally, the influence that three attributes of spokes-characters affect brand trust are different, too. Therefore, when enterprises consider which attribute should be focused on, they should be determined to pay more attention to which result.

\subsection{Limitation and Further Study}

Due to limit of time and effort, the study has some limitations. Firstly, the questionnaire is forwarded by friends around, so the scope may not be wide enough. In the future, we should expand the scope of interviewees, like increasing the number of interviewees in more other provinces. Besides, the model seems a little simple due to the lack of moderating variable. In the future some appropriate moderating variables are considered to be adding into the model, such as other characteristics of consumer, customer involvement and so on.

\section{References}

Aaker, D. A. (1991). Managing Brand Equity: Capitalising on the Value of a Brand Name. New York: The Free Press.

Brown, G. H. (1952). Brand loyalty - fact or fiction? Advertising Age, 23, 53-55.

Callcott, M. F., \& Alvey, P. A. (1991) Toons Sell and Sometimes They Don't: An Advertising Spokes-character Typology and Exploratory Study. Proceedings of the 1991 Conference of the American Academy of Advertising. New York: D'Arcy Masius Benton and Bowies.

Callcott, M. F., \& Lee, W. N. (1995). Establishing the spokes-character in academic inquiry: historical overview and framework for definition. Advances in Consumer Research.

Callcott, M. F., \& Phillips, B. J. (1996). Observations: Elves make good cookies: creating likable spokes-character advertising. Journal of Advertising Research, 36(5), 73-79.

Chang, K. (2008). The effectiveness of the spokes-character in creating brand equity. Society for Marketing Advances Proceedings. 
Delgado, E., Munuera, J. L., \&Yagüe, M. J. (2003). Development and validation of a trust scale. International Journal of Market Research, 45(1), 35-56.

Delgado-Ballester, E. (2003). Development and validation of a brand trust scale. International Journal of Market Research, 45(1), 335--353.

Deng, A. M., Tao, B., \& Ma, Y. Y. (2004). Empirical study of influential elements of e-loyalty. Chinese Journal of Management Science, 22(6), 94-102.

Dipayan, B., Abhijit, B., \& Neel, D. (2006). The differential effects of celebrity and expert endorsements on consumer risk perceptions. The role of consumer knowledge, perceived congruency, and product $\begin{array}{lllll}\text { technology orientation. Journal of Advertising, } & 35(2), & \text { 17-31. }\end{array}$ https://doi.org/10.1080/00913367.2006.10639231

Dong, D., H., \& Jin, Y. F., (2003). A meta-analysis of antecedents of behavioral intention. Nankai Business Review, 6(6):46-51.

Dwane, H. (1999). Brand endorsement, popularity, and event sponsorship as advertising cues affecting consumer $\begin{array}{lllll}\text { pre-purchase attitudes. Journal of } & \text { Advertising, } & \text { 28(3), } & \text { 1-12. }\end{array}$ https://doi.org/10.1080/00913367.1999.10673585

Dwane, H. D., \& Abhijit, B. (2001). Third-party organization endorsement of products: an advertising cue affecting consumer pre-purchase evaluation of goods and services. Journal of Advertising, 30(4), 41-57. https://doi.org/10.1080/00913367.2001.10673650

Dwyer, F. R., Schurr, P. H., \& Oh, S. (1987). Developing buyer-seller relationships. Journal of Marketing, 51(2), 11-27.https://doi.org/10.2307/1251126

Erdem, T., Swait, J. (1998). Brand equity as a signaling phenomenon. Journal of Consumer Psychology, 7(2), 131-157. https://doi.org/10.1207/s15327663jcp0702_02

Fowler, M. (2003). Fifteen critical success factors for real-time customer loyalty: with thoughtful planning, rewarding customer loyalty can pay off handsomely for you and them. Restaurant Hospitality (August).

Freiden, J. B. (1984), Advertising Spokesperson Effects: An Examination of Endorser Type and Gender on Two Audience. Journal of Advertising Research, 24(05), 33-41.

Gremler, D. D., \& Brown, S. W. (1996). Service loyalty: its nature, importance, and implications.

Gwinner, K. P., Gremler, D. D., \& Bitner, M. J. (1998). Relational benefits in services industries: the customer's perspective. Journal of the Academy of Marketing Science, 26(2), 101.https://doi.org/10.1177/0092070398262002

Jacoby, J., \& Chestnut, R. (1978). Brand loyalty measurement and management. Journal of Marketing Research, $15(15)$.

Judith, A. G., \& Ronald, W. N. (2004). Spokes-characters: Creating character trust and positive brand attitudes. Journal of Advertising, 33(2), 25-36. https://doi.org/10.1080/00913367.2004.10639159

Judith, A. G., Folse, R. G. N., \& Scot, B. (2012). Spokes characters. Journal of Advertising, 41(1), 17-32. https://doi.org/10.2753/JOA0091-3367410102

Kamen, J. M., Azhari, A. C., \& Kragh, J. R. (1975). What a spokesman does for a sponsor. Journal of Advertising Research, 17-24.

Kotler, P. (1973). Marketing management: Analysis, planning, implementation, and control. Prentice-Hall.

Lau, G. T., \& Lee, S. H. (1999). Consumers' trust in a brand and the link to brand loyalty. Journal of Market-Focused Management, 4(4), 341-370. https://doi.org/10.1023/A:1009886520142

Lin, H. Y. (2012). The influence of animated spokes-characters on customer orientation-kuo-weilin, ya-junwang. International Journal of Organizational Innovation.

Ma, Q. X., \& Zhang, P. W. (2003). An Analysis of Factors Affecting Customer Loyalty, Regional Economic Review, (4), 34-35

Margaret, F. C, \& Wei-Na, L. (1994). A content analysis of animation and animated spokes-characters in television commercials. Journal of Advertising, $23(4), \quad 1-12$. https://doi.org/10.1080/00913367.1943.10673455

Mize, J., Kinney, L. (2008).Spokes-character Influence on Brand Relationship Quality Factors. American 
Academy of Advertising. Conference Proceedings, 177-187.

Moorman, C., \& Zaltman. (1992). Relationships between Providers and Users of Market Research: The Dynamics of Trust Within and Between Organizations, Journal of Marketing Research, 29(29), 314-328. https://doi.org/10.2307/3172742

Mowen, J. C., \& Brown, S. W. (1981). On explaining and predicting the effectiveness of celebrity endorsers. Advances in Consumer Research.

Peng, B., \& Cao, G. L. (2011). Brand spokesperson 's role in brand and selection. Modern Management Science, (12), 17-19.

Rotter, J. B. (1967). A new scale for the measurement of interpersonal trust. Journal of Personality, 35(4), 651. https://doi.org/10.1111/j.1467-6494.1967.tb01454.x

Spears, N. E., Mowen, J. C., \& Chakraborty, G. (1996). Symbolic role of animals in print advertising: content analysis and conceptual development. Journal of Business Research, 37(2), 87-95. https://doi.org/10.1016/0148-2963(96)00060-4

Sweeney, J., \& Swait, J. (2008). The effects of brand credibility on customer loyalty. Journal of Retailing \& Consumer Services, 15(3), 179-193. https://doi.org/10.1016/j.jretconser.2007.04.001

Viren, S., \& Eliana, G. H. (2008). A beauty-map of london: Ratings of the physical attractiveness of women and men in london's boroughs. Personality and Individual Differences, 45, 361-366.https://doi.org/10.1016/j.paid.2008.05.005

Yoo, B., \& Donthu, N. (2001). Developing and validating a multidimensional consumer-based brand equity scale. Journal of Business Research, 52(1), 1-14. https://doi.org/10.1016/S0148-2963(99)00098-3

Yuan, D. (2007). Research on the structure of brand trust and its measurement. Psychological Exploration.

Zhang, N. (2012). The Influence of Spokes-characters on Brand Equity: The Mediation of Brand Experience and the Moderation of Characteristics of the Consumers and Products. Wuhan: Wuhan University

Zhang, X., Tian, P., \& Zhu, G. (2003). An examination on the relationship between perceived performance, customer satisfaction and loyalty. Nankai Business Review.

Zhou, Z. (2009). The exploratory study on driving factors of brand relationships_- the sample of young people. Chinese Journal of Management, 6(10), 1384-1391.

Zhou, Z. M. (2008). Brand Management. Tian Jin: Nankai University Press.

\section{Copyrights}

Copyright for this article is retained by the author(s), with first publication rights granted to the journal.

This is an open-access article distributed under the terms and conditions of the Creative Commons Attribution license (http://creativecommons.org/licenses/by/4.0/). 